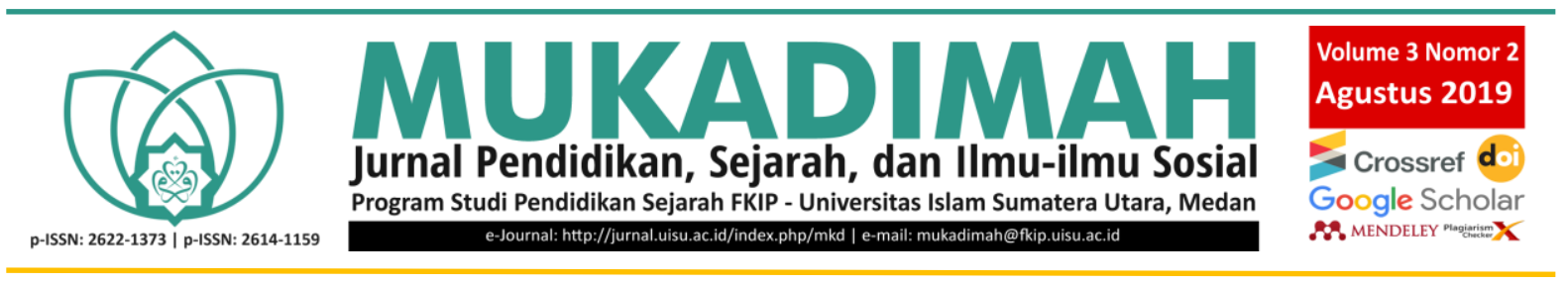

\title{
STRATEGI PEMASARAN HOMESTAY DI KABUPATEN SAMOSIR (Studi Homestay di Desa Huta Tinggi Kecamatan Pangururan)
}

\author{
Asmah Kartika Dalimunthe* \\ Politeknik Pariwisata Medan
}

\begin{tabular}{l}
\hline Article History \\
\hline Submitted: July 1, 2019 \\
Accepted : August 1, 2019 \\
Published : August 10, 2019
\end{tabular}

\begin{tabular}{l}
\hline Kata Kunci \\
\hline $\begin{array}{l}\text { Strategi pemasaran, } \\
\text { perencanaan, homestay. }\end{array}$
\end{tabular}

perencanaan, homestay.

\begin{abstract}
Abstrak
Penelitian ini terfokus kepada menganalisis strategi perencanaan dan pemasaran homestay yang selama ini sudah dilakukan di Desa Huta Tinggi. Pendekatan dan metode yang digunakan kualitatif dan metode yang digunakan deskriptif kualitatif dimana dalam proses pemerolehan data, peneliti terlibat langsung dengan informan turis lokal maupun mancanegara dan para pelaku pariwisata dan mengadakan survey langsung ke objek yang diteliti. Dari hasil analisa dan pengolahan didapatkan hasil tentang: 1) setiap pelaku usaha homestay harus memiliki keunggulan atas yang lainnya; 2) perencanaan homestay melibatkan semua komponen masyarakat dan 3) berdasarkan faktor internal dan eksternal maka strategi yang dilakukan intensif atau integratif. Strategi intensif merupakan strategi dengan cara penetrasi pasar, pengembangan produk dan pengembangan pasar, sedangkan strategi integratif dilakukan dengancara integrasi ke depan, integrasi ke belakang dan integrasi. Peningkatan kualitas pelayanan termasuk juga sarana dan prasarana perlu ditingkatkan. Peran serta masyarakat, stakeholders dan Pemerintah merupakan hal mutlak yang tidak bisa diabaikan. Selain itu penyuluhan program Sapta Pesona kepada tokoh masyarakat khususnya para generasi muda bahwa aset yang dimiliki mempunyai daya tarik yang tinggi harus ditanamkan secara berkesinambungan.
\end{abstract}

\section{PENDAHULUAN}

Samosir merupakan sebuah pulau yang terletak di Kabupaten Samosir dan memiliki daerah yang berpotensi wisata yang berbasis pemandangan alam, wisata spiritual, wisata pertanian, wisata budaya dan perairan Danau Toba. Dengan seiringnya bertambahnya tingkat kunjungan yang datang ke Pulau Samosir, bagaimana dengan tingkat hunian homestay yang ada di pedesaan seperti di Desa Huta Tinggi Kecamatan Pangururan Kabupaten Samosir, seperti judul yang diangkat dalam penelitian ini yang berjudul "Strategi tentang Perencanaan dan Pemasaran Homestay di Desa Huta Tinggi Kecamatan Pangururan Kabupaten Samosir Provinsi Sumatera Utara”.

\section{METODE DAN FOKUS PENELITIAN}

Metode yang digunakan dalam penelitian ini adalah pendekatan kualitatif dan metode penelitian yang digunakan yaitu metode penelitian deskriptif kualitatif. Menurut Bodgan dan Taylor (Moleong, 2007, p. 3) yang dimaksud dengan "metode kualitatif sebagai prosedur penelitian yang menghasilkan data deskriptif berupa kata-kata tertulis atau lisan dari orang-orang yang perilakunya diamati”. 


\section{HASIL DAN PEMBAHASAN}

\section{Analisa Lingkungan Internal}

1) Pemasaran

Salah satu upaya yang dapat dilakukan untuk memenangkan persaingan adalah merubah keunggulan bersaing (competitive advantage) menjadi nilai tambah yang dimiliki pihak pelaku usaha homestay yang ada di Desa Huta Tinggi adalah antara lain:

1) Service Nice, yaitu para pihak pengelola hotel mendorong untuk memberikan service yang menciptakan serangan yang positif buat para pengunjung yang menginap di hotel tersebut;

2) Tarif yang dikenakan dan biaya sangat terjangkau.

Tabel Analisa Usaha Homestay

\begin{tabular}{|l|r|}
\hline \multicolumn{1}{|c|}{ Modal Awal } & Biaya Pengeluaran \\
\hline - Renovasi Rumah & Rp. 42.000.000,- \\
- Pengadaan Perlengkapan Kamar dan Ruang lain & Rp. 53.000.000,- \\
Jumlah & Rp. 95.000.000,- \\
\hline \multicolumn{1}{|c|}{ Total Biaya Operasional } & Total Biaya Pengeluaran \\
\hline - Sewa Rumah & Rp. 2.500.000,- \\
- Sabun mandi dan cuci & Rp. $150.000,-$ \\
- Kebersihan & Rp. $220.000,-$ \\
- Gaji Karyawan 3 orang @ Rp. 1.000.000 & Rp. $3.000 .000,-$ \\
- Makan pagi 30 hari x 4 kamar x Rp. 13.000 & Rp. $1.560 .000,-$ \\
Jumlah & Rp. 7.430.000,- \\
\hline
\end{tabular}

Sumber: Data diolah 2017

\section{Analisa Lingkungan Eksternal}

1) Persaingan pelaku usaha homestay

Para pengusaha jasa penginapan homestay pesaing yang akan mulai ataupun rencana untuk membangun homestay yang ada di Desa Huta Tinggi ini.

2) Ekonomi

Keadaan ekonomi yang tidak menentu dimana inflasi mempengaruhi tingkat perekonomian seseorang, sehingga akan membuat konsumen yang beralih pada penginapan homestay yang lebih murah yang ada di tempat lain khususnya di Kecamatan Pangururan.

Selanjutnya faktor peluang dan ancaman yang diuraikan di atas dimasukkan ke dalam External Factor Evaluation Matrix berikut ini: 
Tabel External Factor Evaluation Matrix

\begin{tabular}{|c|c|c|c|c|}
\hline Faktor Strategi Eksternal & Kode & Bobot & Rating & $\begin{array}{l}\text { Bobot } x \\
\text { Rating }\end{array}$ \\
\hline \multicolumn{5}{|l|}{ Peluang } \\
\hline 1. Perkembangan teknologi & $\mathrm{A}$ & 0,13 & 2 & 0,26 \\
\hline $\begin{array}{l}\text { 2. Target pasar pada masyarakat } \\
\text { berpenghasilan rendah }\end{array}$ & B & 0,18 & 3 & 0,54 \\
\hline 3. Pertumbuhan penduduk & $\mathrm{C}$ & 0,16 & 3 & 0,48 \\
\hline 4. Pertumbuhan pemukiman & $\mathrm{D}$ & 0,13 & 4 & 0,52 \\
\hline Sub Total & & & & 1,80 \\
\hline \multicolumn{5}{|l|}{ Ancaman } \\
\hline 1. Pesaing potensial & $E$ & 0,14 & 3 & 0,42 \\
\hline 2. Laju inflasi tinggi & $\mathrm{F}$ & 0,15 & 2 & 0,30 \\
\hline 3. Kenaikan tarif listrik dan air & G & 0,11 & 3 & 0,33 \\
\hline Sub Total & & & & 1,05 \\
\hline Total & & 1,00 & & 2,85 \\
\hline
\end{tabular}

Sumber: Data diolah 2017

\section{Formulasi Strategi}

Dari matriks EFAS dan IFAS yang telah diperoleh sebelumya, kemudian disatukan untuk mendapatkan matriks I-E.

Tabel Matriks I-E

\begin{tabular}{|c|c|c|c|c|}
\hline Faktor-faktor Strategi & KODE & Bobot & Rating & $\begin{array}{c}\text { Bobot } x \\
\text { Rating }\end{array}$ \\
\hline \multicolumn{5}{|l|}{ Kekuatan } \\
\hline 1. Service Nice & A & 0,11 & 3 & 0,33 \\
\hline 2. Pemilihan fasilitas yang mampu menarik pengunjung & $\mathrm{B}$ & 0,11 & 2 & 0,22 \\
\hline 3. Tarif rendah & $\mathrm{C}$ & 0,15 & 4 & 0,60 \\
\hline 4. Pertumbuhan kunjungan tinggi & $\mathrm{D}$ & 0,13 & 4 & 0,52 \\
\hline Sub Total & & & & 1,67 \\
\hline \multicolumn{5}{|l|}{ Kelemahan } \\
\hline 1. Fasilitas tidak memadai & $\mathrm{E}$ & 0,13 & 3 & 0,39 \\
\hline 2. Kurangnya fasilitas fisik & $\mathrm{F}$ & 0,13 & 3 & 0,39 \\
\hline 3. Sarana pendukung belum memadai & G & 0,11 & 2 & 0,22 \\
\hline 4. Pembiayaan dalam penunjang fasilitas masih berkurang & $\mathrm{H}$ & 0,13 & 3 & 0,39 \\
\hline Sub Total & & & & 1,39 \\
\hline Total & & 1,00 & & 3,06 \\
\hline \multicolumn{5}{|l|}{ Peluang } \\
\hline 1. Perkembangan teknologi & A & 0,13 & 2 & 0,26 \\
\hline $\begin{array}{l}\text { 2. Target pasar pada masyarakat berpenghasilan } \\
\text { rendah }\end{array}$ & B & 0,18 & 3 & 0,54 \\
\hline 3. Pertumbuhan penduduk & $\mathrm{C}$ & 0,16 & 3 & 0,48 \\
\hline 4. Pertumbuhan homestay & $\mathrm{D}$ & 0,13 & 4 & 0,52 \\
\hline Sub Total & & & & 1,80 \\
\hline \multicolumn{5}{|l|}{ Ancaman } \\
\hline 1. Munculnya pesaing baru (pelaku usaha) & $\mathrm{E}$ & 0,14 & 3 & 0,42 \\
\hline 2. laju inflasi tinggi & $\mathrm{F}$ & 0,15 & 2 & 0,30 \\
\hline 3. Kenaikan tarif listrik dan air & G & 0,11 & 3 & 0,33 \\
\hline Sub Total & & & & 1,05 \\
\hline Total & & 1,00 & & 2,85 \\
\hline
\end{tabular}

Sumber: Data diolah 2017 
Analisa internal diperoleh skor tertimbang 3,06, sedangkan dari hasil analisis eksternal diperoleh skor tertimbang 2,85 . berdasarkan komposisi ini maka pada ruang IV seperti yang terlihat pada tabel di bawah ini.

Tabel Internal Eksternal Matriks

IFAS

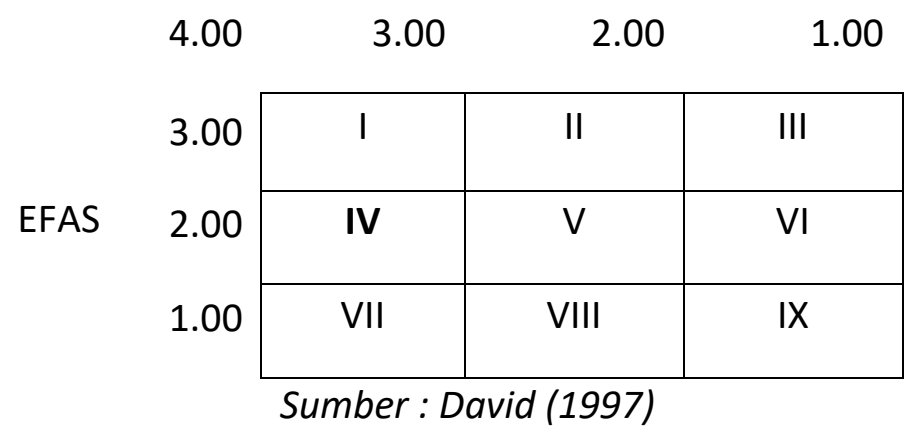

Menurut David A. Aaker (Aaker, 1997), ruang IV adalah posisi pada Growth and Build. Maka strategi yang harus dilakukan adalah strategi intensif atau integratif.

\section{PENUTUP}

\section{Kesimpulan}

Berdasarkan pada teori analisa SWOT (strength, weakness, opportunity, and threat) bahwa untuk masa depan pada suatu perusahaan/homestay, maka pelaku usaha harus mengetahui situasi dan kondisi perusahaan.

1. Analisa faktor-faktor internal

Setiap pelaku usaha wisata dalam menjalankan penginapan/ homestay tanpa terkecuali harus memiliki beberapa keunggulan atas yang lainnya, sebaliknya juga tidak terlepas dari kelemahan-kelemahannya.

2. Analisa faktor-faktor eksternal

Perumusan, strategi, kebijaksanaan serta taktik dirancang untuk mengarahkan pelaku usaha homestay dalam mencapai tujuan secara nyata, namun sebelum strategi dirumuskan, pihak perencanaan harus mengidentifikasi, menganalisa serta mendiagnosa peluang dan ancaman yang ada dalam lingkungannya.

3. Berdasarkan penganalisaan dari faktor internal dan eksternal melalui matrik I-E, maka strategi bersaing yang harus dilakukan kedepan adalah strategi intensif atau integratif.

\section{Saran}

Dalam menjalankan usahanya untuk mencapai tujuannya sesuai dengan misinya, serta dalam pengembangan strategi untuk merebut peluang pasar jasa penginapan/homestay, penulis memberikan masukan yang mungkin dapat digunakan sebagai bahan pengembangan. 
1. Melihat dari jumlah kunjungan dari tahun ketahun mengalami penigkatan yang lebih tinggi, maka sebaiknya pihak pengelolaan homestay melakukan perbaikanperbaikan dan peningkatan sumber daya manusia serta peningktan sarana dan prasarana fasilitas yang ada.

2. Di dalam memanfaatkan peluang pasar dan memperbesar kesempatan pertumbuhan usaha, maka sebaiknya pihak pengelola homestay harus dapat memberikan keyakinan pada pengunjung bahwa penginapan/homestay memiliki pelayanan, keamanan dan khususnya kenyamanan bagi pengunjung.

\section{UCAPAN TERIMA KASIH}

Penulis mengucapkan terima kasih kepada para informan yang telah menyediakan waktu dan memberikan infromasi dalam penyelesaian karya ilmiah ini.

\section{REFERENSI}

Aaker, David A. (1997). Manajemen Ekuitas Merek: Memanfaatkan Nilai dari Suatu Merek. Cetakan Pertama. Jakarta: Mitra Utama.

Aaker, David. (1997). Manajemen Ekuitas Merek. Jakarta: Spektrum.

Fandeli, Chafid. (1995). Dasar-Dasar Manajemen Kepariwisataan Alam. Yogyakarta: Liberty.

Moleong, Lexy J. (1989). Metodologi Penelitian Kualitatif. Bandung: Remadja Rosdakarya

Steiner, George A. (1979) Strategic Planning. New York: The Free A Division of Macmillan Publishing Co. Inc.

Wahab, Salah. (1992). Pemasaran Pariwisata. Jakarta: PT. Pradnya Paramita.

Yoeti, Oka. (1996). Pengantar Ilmu Pariwisata. Bandung: Penerbit Angkasa.

Yoeti, Oka. (1999). Ekonomi Pariwisata, Sejarah, dan Prospeknya. Yogyakarta: Kanisius. 